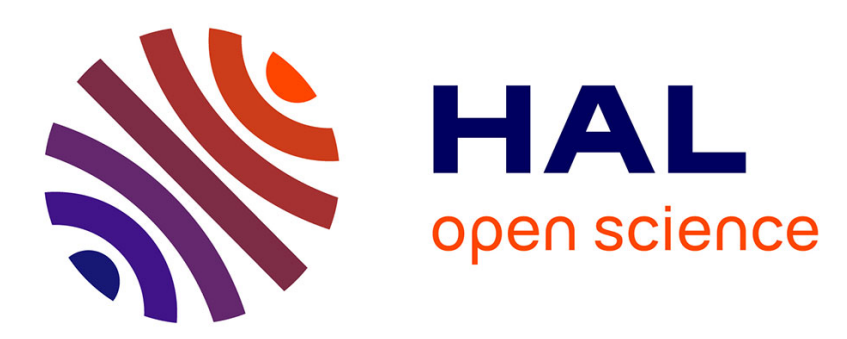

\title{
Taming Tax Competition with a European Corporate Income Tax
}

Fabien Candau, Jacques Le Cacheux

\section{To cite this version:}

Fabien Candau, Jacques Le Cacheux. Taming Tax Competition with a European Corporate Income Tax. Revue d'Economie Politique, 2018, 128 (4), pp.575. 10.3917/redp.284.0575 . hal-02138622

\section{HAL Id: hal-02138622 \\ https://hal.science/hal-02138622}

Submitted on 23 May 2019

HAL is a multi-disciplinary open access archive for the deposit and dissemination of scientific research documents, whether they are published or not. The documents may come from teaching and research institutions in France or abroad, or from public or private research centers.
L'archive ouverte pluridisciplinaire HAL, est destinée au dépôt et à la diffusion de documents scientifiques de niveau recherche, publiés ou non, émanant des établissements d'enseignement et de recherche français ou étrangers, des laboratoires publics ou privés. 


\title{
Taming Tax Competition with a European Corporate Income Tax
}

\author{
Fabien Candau*and Jacques Le Cacheux ${ }^{\dagger}$ \\ Published in Revue d'économie politique 2018/4 (Vol. 128), pages 575 à 611
}

\begin{abstract}
This article proposes an original review of the literature on tax competition, and provides new evidence concerning different types of footloose capital: the intensity of strategic interactions is three time stronger for financial assets than for less mobile capital (e.g. industrial buildings). We also present tax optimization techniques used by Multi-National Firms (MNFs) and document some case studies regarding the foregone tax revenue due to evasion. Amounts saved by firms are comparable to the annual contributions to the EU budget by countries like the UK, Ireland, the Netherlands or Luxembourg. We estimate that the total revenue losses for the EU governments due to corporate tax avoidance amount to almost 100 billion $€$. After this description of the failure of the current system of taxation, this article analyzes alternative schemes such as the Common Consolidated Corporate Tax Base (CCCTB) and concludes with the outlook of a European corporate income as a genuine own resource for the EU budget.
\end{abstract}

\section{Introduction}

While cases of tax evasion by multinational corporations have made headline news in recent years, slow economic growth, high unemployment rate and significant public debt burdens

*UPPA, CATT. Av Poplawski, 64000 Pau. E-mail : fabien.candau@univ-pau.fr

†UPPA, CATT. Av Poplawski, 64000 Pau 
characterize the economy of many European countries. Since the financial crisis of 20072008 and the 2009 Great Recession, this situation has raised concerns about the possibility to tax multinational firms. According to the OECD (2013a, b; 2015) and IMF (2015) the fact that multinational companies manipulate and shift their profits to low tax countries generates a serious erosion of the tax base. Due to the increasing mobility of capital, tax rates on profits of corporations have continously been under downward pressure in Europe. Low-tax jurisdictions such as Ireland, Luxembourg, the UK and some Eastern European Member States have pursued competitive strategies, compelling all the European members to follow suit and to increasingly rely on tax revenues from less-mobile sources such as real property, consumption and labor. Immobile agents (domestic firms, workers) are asked to contribute more while multinational firms exploit tax loopholes at the expense of high-tax countries in which these firms operate and sell most of their products. Tax competition has been the rule, leading to a 'race to the bottom' on statutory tax rates and discriminatory tax treatments. In this article, we survey the literature on tax competition, we show how, without coordination, trade integration is welfare improving when capital is taxed at the federal level and detrimental when taxed at the national one. We also provide new evidence on tax competition concerning different types of capital and we discuss how the increasing mobility of capital amongst EU Member States can legitimate a European tax on multinational firms. This article also documents the failure of the current system of taxation characterized by tax shopping, transfer pricing and tax competition leading to tax base erosion in many European countries. Case studies estimating the lost tax revenue due to evasion by a handful of firms (Apple, Amazon, Fiat, etc.) report significant amounts of revenue losses. By estimating these revenue losses for the EU15 in a more general way, we find an amount of approximately 100 billion euro. After this description of the failure of the current system of taxation, this article analyzes alternative schemes such as the Common Consolidated Corporate Tax Base (CCCTB) proposed by the EU Commission. We emphasize the political difficulties of this reform and its consequences on competition between members. But CCCTB could serve as a basis for a European corporate income tax to finance the European budget by genuine own resources. Instead of losing their fiscal sovereignty without compensation, Member States can decide to transfer or delegate their weak power to tax capital to the upper, EU level. 
Such a decision would improve the fairness and the efficiency of the European market but also the ability to launch European policies.

\section{A simple model of the detrimental effect of tax com- petition in the single market}

\section{$2.1 \quad$ The model}

A robust conclusion of the literature on horizontal tax competition is that, with a limited number of governments competing from a mobile tax base, the equilibrium outcome will be sub-optimal in the provision of public goods -insufficient, in volume and quality, compared to an equilibrium with centralized taxation-, due to the existence of horizontal tax externalities. ${ }^{1}$ This under-provision of public goods has been analyzed mainly by considering that the economical environment is fixed, i.e. whithout taking into account integration in the market of goods and services. Here we follow the economic geography literature ${ }^{2}$ which provides useful tools to better understand how tax competition evolves with trade integration in a single market. More precisely our analysis is built on the so-called "Footloose Capital Model" of Martin and Rogers (1995). ${ }^{3}$ There are two countries, respectively denoted A and B, and two sectors, a Constant Returns to Scale (CRS) activity, agriculture, that produces a homogeneous good under perfect competition and an Increasing Returns to Scale (IRS) activity that produces differentiated services (or manufacturing goods, what matters is not the nature of goods but the process of production and the competition in this market). There are two factors of production, labour and capital. Each country is endowed with K and L

\footnotetext{
${ }^{1}$ See Wilson, 1986; Zodrow and Mieszkowski, 1986; Wilson and Wildasin, 2004; and for a survey of theory and evidence in the EU, Saint-Etienne and Le Cacheux, 2005

${ }^{2}$ See Andersson and Forslid (2003), Baldwin and Krugman (2004), Baldwin, Forslid, Martin, Ottaviano and Robert-Nicoud (2004), Ottaviano and van Ypersele (2005), Borck and Pfluger (2006) and Candau (2008.a) for theoretical models linking trade integration and tax competition. Candau (2008.b) provides a survey of this literature.

${ }^{3}$ Discussions on the main assumptions of this model are motivated and explained in details in Baldwin et al. (2004).
} 
units of factors. Workers are employed in the CRS activity as well as in the IRS and are immobile geographically. In contrast capital is footloose. The preference of the representative consumer is represented by the following quasi-linear utility function:

$$
U=F+\ln \left[S^{\mu}(1+G)^{\alpha}\right], \text { with } S=\left[\int_{0}^{n} c_{i}^{\frac{\rho-1}{\rho}} d i\right]^{\frac{\rho}{\rho-1}},
$$

where $F$ is the food consumption, $G$ the public goods consumption, and $S$ is the consumption of a 'basket' of services, $n$ the number of services, $c_{i}$, in this basket, and $\rho>1$ the elasticity of substitution between these products. The budget constraint is given by $P S+p_{F} F=Y$, where $p_{F}$ is the food price and $P=\left(\int_{0}^{n} p_{i}^{1-\rho} d i\right)^{\frac{1}{1-\rho}}$ the price index of the different kinds of services with $p_{i}$ the price of a typical service $i$.

Concerning the cost function in the IRS sector, the fixed cost involves $f_{i}$ units of capital and the variable cost requires $v_{i}$ units of workers. Thus the total cost of producing $q$ services in country $i$ is $T C_{i}=f r_{i}+v w q_{i}$ where $r$ denotes capital owners' rent and $w$ workers' wage. Each firm is a monopolist on the production of its variety and by maximizing its profit (under the Dixit-Stiglitz monopolistic competition assumptions) sets $p_{i}=v w \rho /(\rho-1)$. Because there is free entry and exit, profits are always equal to zero, which gives the level of output $q_{i}=(\rho-1) f r_{i} / v w$.

By denoting $s_{i}$ the share of domestic firms in $i$, the supply of capital there is given by $s_{i} K$ (capital endowment is $K$ in each country). In equilibrium, a typical firm employs $f$ units of capital, so that the total demand in $i$ is $f n_{i}$. The equalization gives the number of services produced: $n_{i}=s_{i} K / f$. Trade costs (that can be time costs, transport costs and transaction costs) are assumed in the IRS sector, if a service produced in A is sold at price $p$ on it, then the delivered price of that variety in B is going to be $\tau p$ with $\tau>1$.

Wage in the agricultural sector, $w$, is taken as the numeraire and we also set $K=1$ and $f=1$ to simplify expression. Considering total demand in $A$ as the sum of the local and export demands and equating this demand to the supply gives (after rearrangement and by inserting price index) the following market clearing equation:

$$
r_{A}=\frac{\mu}{\rho}\left(\frac{L_{A}}{\Delta_{A}}+\frac{L_{B}}{\Delta_{B}} \phi\right)
$$

with $\Delta_{i}$ a measure of the aggregate price of services in $i: \Delta_{A} \equiv s_{A}+\left(1-s_{A}\right) \phi$ and $\Delta_{B} \equiv$ $s_{A} \phi+1-s_{A}$, where $\phi$ measures trade "freeness": $\phi=\tau^{1-\rho}$. This degree of trade liberalization 
increases from $\phi=0$ with infinite trade costs to $\phi=1$ with zero trade costs. Ceteris paribus, an increase in $s_{A}$ implies, as long as there are transaction costs $(\phi<1)$, a decrease in the price index in A, i.e. an increase in $\Delta_{A}$ :

$$
\frac{\partial \Delta_{A}}{\partial s_{A}}=-\frac{\partial \Delta_{B}}{\partial s_{B}}=1-\phi>0
$$

As a result more capital in $\mathrm{A}$ has two different effects, on the one hand it means more competition in this country and thus reduces the capital reward (1), on the other hand because services are cheaper, the purchasing power is increasing in A with the agglomeration of capital. By summing indirect utility of capital owners and workers we analyze the following utilitarian social welfare function in $i=A, B$ :

$$
V_{i}=\left(1-t_{i}^{L}\right) L_{i}+\left(1-t_{i}^{K}\right) s_{i} r_{i}+2 a \ln \left(1+G_{i}\right)+2 b \ln \Delta_{i}
$$

where $b \equiv \mu /(\rho-1)$ and with $t_{i}^{L}$ and $t_{i}^{K}$ taxes on labour and capital such as $G_{i}=t_{i}^{L} L_{i}+t_{i}^{K} s_{i} r_{i}$.

The location choice of capital is defined by net returns and thus the spatial equilibrium is $\left(1-t_{A}^{K}\right) r_{A}=\left(1-t_{B}^{K}\right) r_{B}$. The sequence of the tax competition game is standard, each government maximizes its objective function by taking as given the tax rate of its competitor and of the federal state and then relocation occurs. The game is resolved by backward induction. Resolving the spatial equilibrium condition using the market clearing equation gives the share of capital at the equilibrium:

$$
s_{A}=\frac{1}{2}\left(1-\frac{t_{A}-t_{B}}{2-t_{A}-t_{B}} z^{2}\right) \text { with } z=\frac{1+\phi}{1-\phi}
$$

This expression indicates that with identical level of taxes the symetrical equilibrium is always stable (Martin and Rogers, 1995). Indeed with $t_{A}=t_{B}$ the capital is equally distribuated between countries $\left(s_{A}=1 / 2\right)$.

Concerning the second step of the tax game, each government maximizes (3) taking as given other taxes. By the symetry of the nations, the Nash equilibrium is given by:

$$
t_{i}^{K}=a+\frac{b \Phi}{2}-\frac{t_{i}^{L}}{2}-\frac{1}{2}\left[\Gamma-\frac{16 a \phi}{\left(1+\phi^{2}\right)}+4 a b \Phi+(b \Phi)^{2}\right]^{1 / 2}
$$

with $\Phi \equiv\left(1-\phi^{2}\right) /\left(1+\phi^{2}\right)$ and $\Gamma \equiv\left(2 a-\left(2+t_{i}^{L}\right)\right)^{2}+2\left(2+t_{i}^{L}\right) b \Phi$. 
From this expression it can be prove easily that this tax rate is decreasing in trade costs $\left(\partial \Phi / \partial \phi<0\right.$ and $\left.\partial t_{i}^{K} / \partial \Phi>0\right)$, which means that due to trade integration, tax competition leads to a race to the bottom in term of capital taxation.

We can now analyze the welfare of citizens under a centralized and decentralized system. To present this analysis, we consider a federal government that is the sole to tax capital (national governments only tax labour). Since countries are identical, this central government divides its budget equally between the two countries and thus the furniture of public good is given by $G_{i}=t_{i}^{L} L_{i}+t_{c}^{K}\left(s_{A} r_{A}+s_{B} r_{B}\right) / 2$. This government set its tax rate $t_{c}^{K}$ by maximizing the utilitarian utility function presented in (3):

$$
t_{c}^{K}=\frac{2 a-1-L t_{i}^{L}}{L}
$$

This tax rate is not a function of trade integration and decreases with respect to the taxation on labour. By inserting this tax rate (5) in the social welfare function (3) we can analyze how trade integration affect welfare. Figure (1) reports this national welfare and compares it with the welfare obtained under tax competition (inserting (4) in (3)).

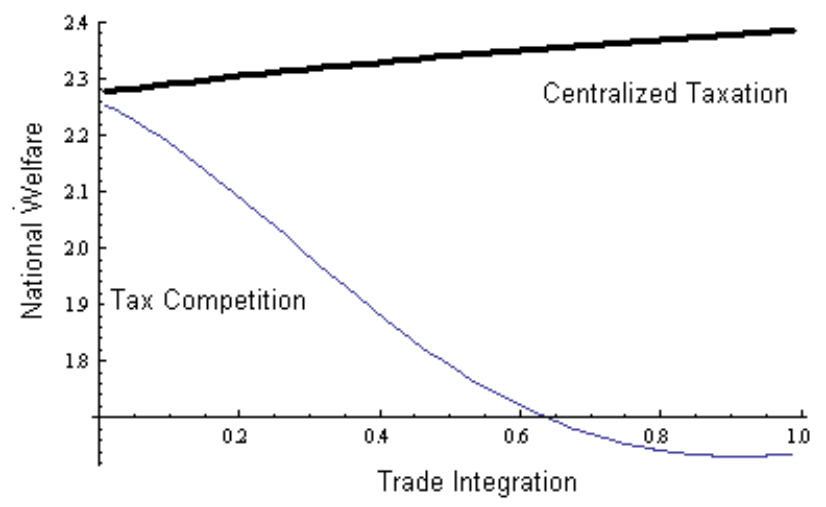

Figure 1: Tax Competition and Integration.

Numerical simulations done with $\rho=6, \mu=0.4, t_{A}^{L}=t_{B}^{L}=0.3, a=1, L=1$.

Result 1 Trade integration is welfare improving when capital is taxed at the federal level and detrimental when taxed at the national level.

There is an under-provision of the public good exacerbated by trade integration. Only a 
central government can restore the fair provision of public goods. ${ }^{4}$ In that last case, trade integration has a positive effect on welfare by reducing the cost of living (see (2) and (3)).

The most compelling argument in favor of a European tax on multinational firms is that the current system allows (and even encourages) Members States to compete with one another in a way that destabilizes the system itself. When trade costs decrease, mobile firms have strong incentives to avoid taxation by playing on national tax systems differences and loopholes. Restoring the ability to tax mobile capital (which is progressively lost by national governments) and reducing the numerous compliance costs encountered by MNFs would allow the European Union to improve both the fairness and the efficiency of the European market.

\subsection{Discussions}

\section{Vertical tax competition}

The previous model provides a radical view considering that only the central government sets a tax on capital in the federal system. When tax bases are shared amongst governments at different levels in a multitier government structure, a vertical tax externality also exists, in the sense that decisions to tax at one level will have an incidence on the size of the tax base for governments at other levels. This creates a strategic interdependence, whose effects in general counteract those of horizontal tax competition:

Result 2 Vertical tax competition tends to mitigate the 'race to the bottom' induced by horizontal tax competition and may partially restore optimality in the provision of public goods (Keen and Kotsogiannis, 2002).

The literature on vertical tax competition is more recent and less abundant than that on horizontal competition; the conclusions are less clear-cut and it suggests that outcomes

\footnotetext{
${ }^{4} \mathrm{~A}$ similar result is obtained by Ottaviano and van Ypersele (2005), they find that in a model with imperfect competition, trade costs and capital, only international tax coordination can implement the efficient spatial distribution of firms. However this result cannot be generalized beyond this footloose capital model with positive trade costs (see Baldwin and Krugman (2004) and Candau (2008.a) who present different results when tax competition concerns entrepreneurs (and not capital)).
} 
depend to a large extent on institutional design and informational structure. But the general conclusion that, introducing a more centralized power of taxation mitigates the inefficiency in public good provision, is generally valid (see Lachet-Touya, 2016).

\section{On the benefit of tax competition?}

Of course, tax competition is not necessarily bad from an economic efficiency viewpoint. It undoubtedly has beneficial effects: by pushing rates down and raising the tax base, it reduces the distortions on market price signals, and hence the deadweight loss generated by taxation, and may force governments to be more efficient in the provision of public goods and better cater to the preferences of their citizens. If we consider for instance a Leviathan government that maximizes its budget then the level of taxation can be excessive and tax competition can tame this bad behavior (Brennan and Buchanan, 1980; Edwards and Keen, 1996)..$^{5}$

However, in the presence of discriminatory tax treatments, there are, often large, efficiency losses due to distortions in firms' location decisions and other costs related to efforts by firms to 'optimize' their tax burdens, as exemplified by the recent cases of tax-motivated mega-mergers.

\section{About incidence}

While public opinion clearly supports the taxation of corporate firms, economists are less prone to recommend this instrument for at least two reasons. The first one is that such a tax introduces distortions and induces unproductive behaviors in order to evade taxation affecting investment, location decisions, international trade and economic growth. But insofar as firms are taxed at the national level, this distortion already exists, and the unproductive strategies they deploy to evade taxation are, as will be shown below, even more damaging in a single market with decentralized taxation than with a single tax authority.

The second one concerns incidence, i.e. the shifting of the corporate tax to some other units in the economics system. Many empirical papers since Harberger (1962) have tried

\footnotetext{
${ }^{5}$ These two different ideas of governance (Leviathan versus Benevolent) however share the same conclusion, tax competition lowers the size of governments.
} 
to analyze who ultimately bears the economic burden of the tax. Multinational firms have the power to absorb the taxation by forward shifting onto consumers by rising prices and/or by backward shifting onto employees (and onto raw material and intermediate suppliers) by reducing wages (or the prices of raw and intermediate goods). Bradford (1978) and Kotlikoff and Summers (1987) show that a tax on corporate income leads to a flight of capital that reduces the return to labor, and thus domestic workers bear the entire burden of the tax. In Randolph (2006) the incidence depends on the proportion of capital in factor income and the author finds that labor bears between $45 \%$ and $75 \%$ of the tax burden. Arulampalam, Devereux and Maffini (2012) by using a sample of European firms find that a $1 \$$ increase in the tax bill reduces real wages by around 50 cents. Hassett and Mathur (2015) by working with a panel of 72 countries over twenty years (1981-2002) find that wages are very responsive to corporate taxation when countries are small.

The question of the country size is indeed crucial in all this literature on distortion and incidence. As argued by Gordon (1986) a small country may be better off by taxing directly the immobile factors since due to the high mobility of capital in these countries, the tax burden inevitably falls on these factors and in addition distorts the allocation of capital. This was also in some sense the result of Harberger (1962): in a closed economy, capital owners pay the tax. Needless to say, Europe is not a closed economy; however the mobility of capital is much weaker between Europe and the rest of the world than between Member States. The agglomeration of consumers and infrastructures and the local preferences of consumers reduce the mobility of capital at the European scale (as we will show in the next section) and as a result the extent to which owners of capital bear the tax burden increases at this level of governance. Thus according to incidence analysis, a corporate tax would be much more efficient if capital were taxed at the European scale than at the national level. 


\section{On the declining power to tax multinational firms at the national level}

\subsection{Globalization: Change in the Playing Field of Footloose Multi- national firms}

For most of the 20th century, globalization was mainly characterized by a spectacular decrease in trade costs. This stark change in the cost of moving goods has led multinational firms to fragment their supply chain in order to benefit of countries' comparative advantages. Factories have been located in low wage countries and headquarters, R\&D or services in countries in which rich customers are agglomerated. The limit of this process resided in the fact that structuring the supply chain involves a continuous investment in communication to coordinate different tasks and thus when information on know-how was hard to transmit on long distances, the production of goods and services were clustered in some limited locations across the world. The new radical change at the end of the twentieth century has been the sharp decrease in the cost of moving information and ideas.

Both horizontally and vertically organized MNFs have grown in reason of economic fundamentals related to market size and access to low-cost local inputs (Markusen, 2002; Navaretti and Venables, 2006), but a growing part of affiliate creations, mergers and acquisitions are now driven by tax determinants. Working with 33,577 European foreign- and domesticallyowned manufacturing plants, Egger, Eggert and Winter (2010) find that on average foreign ownership reduces the tax burden by about 56\%. To sum up, while the transport costs revolution has mainly affected the location choice of physical capital, the Information and Communication Technology revolution (ICT) revolution made it easy to shift profits to lowtax countries.

The financial liberalization of the 1980s has been the first determinant allowing to move

capital worldwide at a lower cost. Internet and the digitalization of the economy has been the second one making possible a deeper fragmentation of the international supply chain. The ICT connected to the computing power has totally modified the transmission capacities of information. Tacit information became codified and easily exchangeable opening up the 
possibility for firms to increasingly operate on a multinational scale (Baldwin, 2017). The world FDI flows, that used to represent only $2 \%$ of the gross domestic capital formation in 1980, have risen to 15\% in the early 2000s and FDI in Europe have increased at a tremendous rate: Inward FDI in the EU28 rose from $21.7 \mathrm{Bn} \$$ in 1980 to $95.6 \mathrm{Bn} \$$ in 1990 , to 680.3 $\mathrm{Bn} \$$ in 2000 , 800.culminating at $824.4 \mathrm{Bn} \$$ in 2007, to reach $566.2 \mathrm{Bn} \$$ in 2016 (UNCTAD, 2015).

Furthermore, intangible assets related to innovation, such patents, trademarks and copyrights or marketing services, are now major sources of profits for multinational corporations and these intangibles are much more mobile than physical capital and can thus be geographically separated from other production units at small costs. Standard examples are found in the ICT sector where the value of the firm is often linked to its innovative technology while the marginal cost of production is low. This process is however not limited to this sector, for instance firms in the pharmaceutical sector typically earn profit from their innovative patents and not from the manufacturing of the drugs which yields only low returns. And firms with valuable trademarks earn profits from their brands and image.

From the AMADEUS database, working on the EU-25 over years 1995-2005, Dischinger and Riedel (2011) observe the growing importance of intangible property in their sample of MNFs, they show that that the mean value of intangible property steeply rises both for the average parent firm and the average subsidiary.

\subsection{Regionalization: Home bias and the European Supply Chain}

Globalization has changed the scale at which multinational firms operate. This globalization is however a complex mix of global and regional exchanges. While MNFs move from countries to countries, for a vast majority of these firms many exchanges are organized around three continents, leading Baldwin (2016) to speak about Asian, American and European factories. Actually, it would be wrong to consider that we live in a world where distance does not matter. ${ }^{6}$ For instance, Portes and Rey (2005) find that physical distance strongly

\footnotetext{
${ }^{6}$ To give one example, the distance elasticity of trade is remarkably high and stable, estimated around -1 over a century at the world level. See Candau and Guepie (2018) who survey the field and discuss this result.
} 
affects international equity flows and holdings: doubling the distance reduces cross-border

equity flows by half. Home bias on international markets, which explained "the desinclination of capital to migrate" (Flandreau, 2006) is still a real phenomenon. Despite financial globalization, US investors still held more than 80 percent of domestic equities in 2007 and similar numbers could be observed in Europe. European investors hold $57 \%$ of domestic equities which is a much higher proportion than the share of European equities in the world market (only 13.5\%). Coeurdacier and Rey (2011) provides a survey documenting this Home Bias in equity.

Informational, institutional, transaction costs but also behavioral bias can explain these results. For instance, it has been known for decades that investors suffer of overconfidence concerning the detention of local assets (French and Poterba, 1991). The recent European debt crisis has also revealed that during the period of growth some European investors have been overconfident on the performance of some European peripheral countries. In many cases, one can observe that investors have a preference for 'familiar' assets and ignore standard portfolio theory on diversification including the geographical one (see Barberis and Thaler, 2003, for a review).

Since European borders still matter for equities, it is not surprising to observe that they also matter for less mobile factors. Physical capital for instance is obviously mobile and relocations towards China or to other emergent or developed countries have been numerous. However the vast majority of exchanges, both in terms of FDI and imports/exports, are between Members States. There is a clear hub-and-spoke offshoring system around highwage countries such as Germany, France and the UK. Germany is obviously the leader of this so-called "bazaar" economy (Sinn, 2003) by selling goods that are partially produced elsewhere in Europe. A vast majority of goods move inside the European Union.

All these results may lead to consider that if the revenues of capital taxation are harder to collect for the Members States, taxing them would be easier at the European scale.

\subsection{Mechanisms for cross-border profit shifting}

Facing these waves of globalization, the European and international rules of taxation seem archaic. In the current system, profits are generally taxed according to the source based 
principle, i.e. where profits have been reported, while interest and royalty payments are deductible at source and taxed in the residence country of the recipient. Initially designed in the 1920s, under the auspices of the League of Nations, such a system was mostly geared at avoiding double taxation.

The problem is particularly serious when firms import and distribute at home, goods produced abroad by subsidiaries. In that case, each entity has to compute its profit by using "transfer prices", in principle set on comparable transactions between unconnected parties. This is the "arm's length pricing" principle. This principle defines how the profits of MNFs are allocated between countries. The main problem is that the manipulation of this principle is widespread in practice. Corporations in high-tax countries tend to sell intermediate goods at low price to their low-tax subsidiaries while these entities export to them at high price. For instance, Hanson, Mataloni and Slaughter (2005) find that the demand of American multinational enterprises for imported inputs is higher when affiliates face lower corporate income tax rates. Vicard (2014) finds that the manipulation of transfer prices in France led multinationals firms to decrease the value of exports by $0.8 \%$ and to increase imports value by $0.5 \%$ in 2008 . This strategy enabled multinational groups to reduce the corporate tax bill they paid in France by $10 \%$ on average, saving approximately 8 bn USD in 2008. Davies, Martin, Parenti, and Toubal (2017) confirm the existence of tax avoidance through transfer pricing in France, but observe that this strategy is concentrated on a small subset of firms (driven by the exports of 450 firms to ten tax havens), which leads them to conclude that significant revenue increases can be obtained by authorities with minimal cost by targeting enforcement.

These analyses naturally underestimate tax avoidance since comparable transactions between unconnected parties to set the transfer prices are not always available to detect the fraud. In developed tertiary economies, such a problem is particularly acute since many incomes are derived from intangible assets related to intellectual property (patents, trademarks, brands and copyrights). For instance when Google transferred its technology in 2003 to its Bermuda subsidiary (just before being listed as a public company), no comparable transaction was available and the fair transfer price (in the arm's length pricing spirit) seems hard, not to say impossible to set. 
A common tax planning strategy is to locate intangible property in a group subsidiary resident in a low-tax country and license it to other group subsidiaries residing in high-tax countries. The most recent and famous practice of this kind is the "Double Irish Dutch sandwich" used by Google. In this evasion scheme, revenues are shuttling back and forth in four "shops": the US, Bermuda, Ireland and the Netherlands.

The historical collective failure to lead tax discussion on a multilateral basis and thus by default the necessity to rely on bilateral agreements is at the origin of treaty shopping. Multinational firms with stateless income tax planning ${ }^{7}$ exploit tax loopholes at the detriment of high-tax countries where these firms operate and sell most of their products. ${ }^{8}$

Transfer pricing (including the location choice of intangible property that benefits of preferential tax treatment in many countries) automatically leads to tax evasion which could explain 70\% of profit-shifting (European Commission, 2015).

Debt shifting is also a common practice to evade taxation. MNFs easily shift profits by financing group companies in high-tax countries offering interest deductibility with intragroup debt from affiliates residing in low-tax countries. Adopted in 1990 and amended in 2003, the European directive on Parent-subsidiary taxation failed to properly address this issue.

\subsection{Some Examples of Tax Optimization}

The Google treaty shopping is maybe one of the most famous; it started in 2003 when Google US sold a part of its business to Google Ireland Holdings which is a subsidiary incorporated in Ireland but that resides in Bermuda. Then, this subsidiary has sold the rights to use its technologies in Europe to a Dutch company, which in turn has licensed the rights to a lower-tier subsidiary, Google Ireland Limited. To avoid paying the 12.5 percent corporate income tax imposed by Ireland, Google Ireland Limited makes deductible royalty payments to its Dutch subsidiary which makes the same royalty payments to Ireland Holdings. This

\footnotetext{
${ }^{7}$ See Kleinbard (2011) for an analysis of the concept "Stateless Income".

${ }^{8}$ Recently, progress has been made thanks to the OCDE "Base Erosion and Profit Shifting" (BEPS) initiative, leading to the adoption of a new set of rules for international tax treaties, including country-bycountry reporting, etc. See: http://www.oecd.org/tax/beps/.
} 
subsidiary is considered as a Bermuda company by Ireland, so no taxation is levied there. Furthermore, this company is Irish from the U.S. and Dutch perspectives, allowing Google to pay an effective tax rate of only $2.4 \%$ and to reduce its tax bill by $\$ 3.1$ billion. $^{9}$

This is the kind of inconsistencies coming from bilateral agreements that allows firms to legally evade taxation.

One may notice that this scheme of evasion widely used by multinational firms is only one example among many. ${ }^{10}$ Here we provide a non exhaustive list of some affairs reported recently by different kind of investigations.

Apple Inc. has used different strategies to evade about $\$ 44$ billion taxes from the US and from source countries. The European Commission has considered that Ireland had provided undue tax benefits of $€ 13$ billion. In 2011 Apple recorded profits of $€ 16$ billion but paid only $€ 10$ million of taxes. This effective rate of $0.05 \%$ has even been divided by 10 in the following years $(0.005 \%$ in 2014$)$.

The EU commission has also launched an investigation on Amazon which has used a tax arrangement in Luxembourg since 2003 to pay no taxes on profits.

Starbucks has also used transfer pricing methods between Switzerland, the Netherlands and the UK to pay in the Netherlands only $€ 2.6$ million in corporate tax on a pretax profit of $€ 407$ million (i.e. an effective tax rate of less than 1\%) which has unfairly reduced its tax burden by $€ 20-30$ million (Commission Decision, 2015).

The European Commission has also found a similar amount of $€ 20-30$ million saved by Fiat Finance and Trade in 2012. The taxable profits declared in Luxembourg were 20 times smaller than total profits thanks to a selective tax advantage provided by the domestic tax authorities, i.e. Fiat paid taxes on a small portion of its actual accounting capital.

Playing on tax treaties concerning royalty payments between the US and Luxembourg, McDonald's has succeeded to pay no tax in either country. These untaxed profits amounted to more than $€ 250$ million in 2013 alone according to the EU Commission. The French tax authority has also considered that the company had reduced its French tax bill on profits by

\footnotetext{
${ }^{9}$ First revealed by Drucker (2010).

${ }^{10}$ The "double Irish" system has been closed in 2015 for new firms and is going to be close in 2020 for past location choices.
} 
€300 million thanks to transfer pricing with McDonald's Inc. Luxembourg and Switzerland.

According to Auerbach (2016), IKEA has also used various schemes such as intracompany loans and tax on royalty to alleviate its tax burden. The tax bill has been reduced by $€ 24$ million in France, $€ 5$ billion in Germany, $€ 11.6$ million in the U.K., etc. IKEA has also exploited Belgian notional interest deduction and sweetheart deals with Luxembourg. Lastly Ikea's corporate groups have used financial arrangements to shift profits from Luxembourg to Lichtenstein. While the total net income declared in Luxembourg was about $€ 15.6$ billion, the company has paid only $€ 477.9$ million (3\%). According to this report, IKEA has avoided at least $€ 1$ billion taxes between 2009 and 2014 .

The retailer Gap has also succeeded to pay almost no tax in the UK by buying royalty fees from its Dutch subsidiary despite its $£ 1$ billion of sales.

More recently, Auerbach (2016) finds that BASF has avoided $€ 923$ million in taxes over the period 2010-2015. The number of techniques used is significant. BASF has evaded the German income tax on foreign-source dividends by using Dutch holding companies, has used the Netherlands participation exemption to avoid taxes on intra-group loans, and has also used the Dutch innovation box to reduce the tax burden on intellectual property income. Lastly the group has used intra-group activities to shift profits to Puerto Rico and Switzerland.

To make these numbers meaningful, Figure (??) and Figure (??) summarize these amounts of tax revenue losses due to tax evasion and compare them to the EU-budget contributions of four countries that have been particularly active in providing tax loopholes: the UK, Ireland, the Netherlands and Luxembourg. Since many investigations have been led around the year 2010, we take that year for the contribution of these countries to the EU budget.

It is striking to observe that the contribution of the UK is equivalent to the tax saved by Apple, and that the Google tax gain is larger than the Netherlands' contribution.

The sum of taxes saved by IKEA, BASF and McDonald's alone is higher than the Ireland and Luxembourg contributions. 


\section{Tax competition}

\subsection{Stylized facts}

\section{Corporate Income Tax}

The wind of change born in the beginning of the 80s has not only changed the mobility of profit, it has also changed the way profits are treated by countries. Once profit became more mobile, competition between countries to attract capital has become fiercer. Tax competition in Europe is however not a new phenomenon. Ever since the completion of the European Single market, tax competition has been on the rise. In the late 1980s, after the adoption of the single European Act, the Commission had expressed concern that tax harmonization might be needed, at least on some of the tax instruments most directly impacted by increased mobility of tax bases. Later on, in the late 1990s, renewed concern was expressed about 'harmful tax competition' in the fields of corporate taxation and the taxation of incomes from personal financial investments (Primarolo Report, 1999). As a response, two measures were adopted: the 'Code of conduct', prohibiting 'damaging' or 'harmful' tax competition - essentially discriminatory tax treatment of foreign firms-- on corporate taxation, and the Savings Directive, that introduced mandatory information exchange on incomes from interest-bearing assets held by non-resident EU citizens.

However these measures have not stopped tax competition, which seems to have been exacerbated by successive enlargements (Davies and Voget, 2011). Exbrayat (2017) reveals that bilateral trade integration gives rise to significant interactions with respect to effective average tax rates in Europe. To illustrate this, Figure (4) reports the mean of corporate income tax rates in the EU (including countries only after each enlargement) and eleven OECD members with European countries before they join the EU.

The decrease in the level of average CIT rates does not represent only a mechanical decline due to the integration of poor countries with historical low level of taxation. Crabbé and Vanderbussche (2013) and Cassette and Patty (2008) show that EU-15 countries in the neighborhood of Central and Eastern Europe have been more engaged in CIT tax competition. 


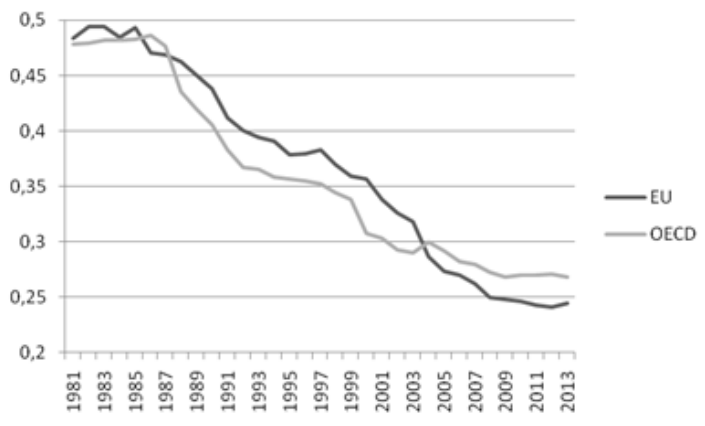

Figure 4: Statutory Corporate Income Tax Rates, 1981-2013.

Calculation based on the OECD Tax Database.

An indirect measure of the extent of profit shifting by firms in response to the various tax loopholes and incentives may be gathered from comparing the composition of GDP in various EU countries: it confirms that small countries tend to have a larger share of profits in GDP than larger ones, the most extreme case being Ireland, especially in recent years as shown in Figure (5).

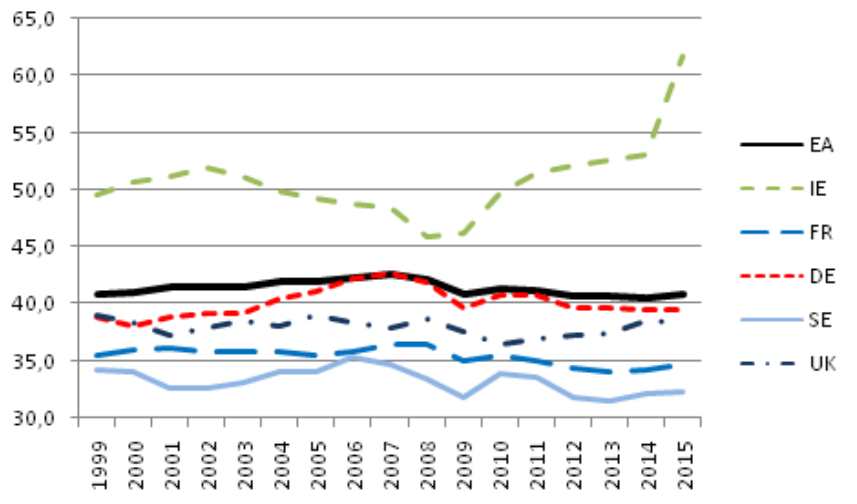

Figure 5: Gross operating surplus, as a percent of GDP, in selected EU countries, 1999-2015. Eurostat.

More recently some other small countries, like Luxembourg, or larger ones like the UK, have taken the leadership of this tax competition game. This competition has been more or less intense depending on the sector considered. For instance, firms in the financial sector have been much more prone to relocation with an estimated marginal effect of taxes that is twice larger in this sector than in manufacturing (Lawless et al., 2017). The recent multiplication of IP box regimes to attract intangible assets certainly also reflects a new field 
of tax competition.

\section{IP Box Regimes}

As previously described, intangible assets are highly mobile and thus are very sensitive to corporate income taxation as shown by Griffith et al. (2014) concerning the location of patents. In response, many European countries have introduced "Intellectual Property (IP) Box regimes" reducing the rate of corporate tax levied on the income derived from patents and intellectual property (Evers et al. 2015). Table (6) below reports the numerous IP box implemented over the past decade.

\begin{tabular}{llll} 
& $\begin{array}{l}\text { Date of } \\
\text { implementation }\end{array}$ & $\begin{array}{l}\text { IP Box } \\
\text { rate (\%) }\end{array}$ & $\begin{array}{l}\text { Main } \\
\text { rate (\%) }\end{array}$ \\
\hline Belgium & 2007 & 6.8 & 33.99 \\
Cyprus & 2012 & 2.5 & 12.5 \\
France & 2000 & 16.76 & 35.41 \\
Hungary & 2003 & 9.5 & 19 \\
Liechtenstein & 2011 & 2.5 & 12.5 \\
Luxembourg & 2008 & 5.84 & 29.22 \\
Malta & 2010 & 0 & 35 \\
Netherlands & 2007 & 5 & 25 \\
Portugal & 2014 & 15 & 30 \\
Spain & 2008 & 12 & 30 \\
Nidwalden, Switzerland & 2011 & 8.8 & 12.66 \\
United Kingdom & 2013 & 10 & 21
\end{tabular}

Figure 6: IP Box regimes in place in Europe in 2014.

Evers, Miller, Spengel (2015).

These preferential tax regimes have been clearly identified as harmful tax practices by the OECD (2013a) and by the European Commission (2013). Alstadsæter et al. (2015) even identify that patent box regimes deter local innovative activities. Recently (in june 2017), the OCDE has asked the French government to repeal the French Patent box regime.

\section{Effective Average and Marginal Tax Rates}

Statutory tax rates analyzed until now matter regarding profit shifting, but to observe the competition of governments to attract investments, the analysis of the Effective Average Tax 
Rates (EATR) is more adequate. This tax rate measures the wedge between the pre- and post-tax return on a typical investment project. Discrete choices of investment made by multinational firms between alternative locations depend on EATR. ${ }^{11}$

Figure (?? $)^{12}$ reports a clear downward trend over the past decades in EATR of the EU28. Not reported here, a similar result has been found for the Effective Marginal Tax Rate (EMTR) which measures the impact of tax on the cost of capital (including financial costs and depreciation).

Another striking result is that the gap between countries varies with the nature of the capital considered. Industrial building which are among the least mobile base, support the highest level of taxation in many countries (Spengel, Endres, Finke, Heckemeyer, 2012). The reverse holds for mobile capital. In France for instance the EATR on financial assets was equal to $40 \%$ in 2014, while this tax rate was nearly $20 \%$ in UK and $16 \%$ in Estonia.

Comparing the different tax rates, the drop in the Statutory tax rate has been more pronounced than the EATR (and EMTR), indicating that taxes are set to attract the most mobile base, while maintaining a relative higher tax on less mobile firms. We analyze this last point in more details in the next section devoted to the consequences of tax competition.

\subsection{Empirical Analysis}

The contribution of this section is to analyze tax competition on different type of capital which remains a difficult exercice due to data limitation. More precisely from Spengel et al. (2012) we collected EATRs on industrial building, intangibles, machinery and inventory assets for 25 European countries ${ }^{13}$ over the period 1998-2012. We also lead a more classical regression by using CIT rates (from Eurostat) for the same sample of European countries but for a longer period of time (1996-2013).

\footnotetext{
${ }^{11}$ See among many studies European Commission (2013) and Devereux and Sorensen (2006).

${ }^{12}$ Source: Based on data from the European Commission (2013)

${ }^{13}$ Herer the 3 letters code (to save space) of these countries AUT, BEL, BGR, CYP, CZE, DEU, DNK, ESP, EST, FRA, GBR, GRC, HRV, HUN, IRL, ITA, LTU, LUX, LVA, MLT, NLD, POL, PRT, SVK and SWE.
} 
To evaluate tax competition in a framework where common shocks, country-specific effects, time and spatial correlation are considered we estimate the following equation:

$$
t_{i, t}=\alpha t_{i, t-3}+\beta \hat{t}_{i, t}+\gamma X_{i, t}+c_{t}+f_{i}+\varepsilon_{i t}
$$

where $t_{i, t}$ is the tax rate sets on a particular capital, $t_{i, t-3}$ is the lagged dependent variable, ${ }^{14}$ $\hat{t}_{i, t}$ is an exogeneous proxy of the average tax rate of other countries, $X_{i, t}$ represents different controls, $c_{t}$ is a common period effect and $f_{i}$ are individual fixed effects. The common period effect aims to control for the recent crisis in Europe by using a dummy that takes one for years 2007, 2008, 2011 and 2012 and zero otherwise. ${ }^{15}$ Considering controls we use the share the share of old and young people ${ }^{16}$, hereafter deoted $O l d_{i, t}$ and oung $_{i, t}$, which are socio-demographic variables often used for their exogeneity.

The average tax rate of other countries is calculated using a weighted scheme $\omega_{i j}$ based on physical distance, $d_{i j}:{ }^{17}$

$$
\bar{t}_{i, t}=\sum_{j \neq i} \omega_{i j t} t_{j t} \omega_{i j t} \equiv \frac{1 / d_{i j}}{\sum_{j \neq i}\left(1 / d_{i j}\right)}
$$

However, this average tax of partners presents a major drawback: in the presence of strategic interactions on tax rates, this explanatory variable can be a function of the dependent variable $t_{i, t}$ leading to a biased estimation of tax competition. To deal with this endogeneity bias, we adopt an intrumental approach in two-steps, where in the first one the following regression is performed:

$$
\bar{t}_{i, t}=\beta_{1} \sum_{j \neq i} \omega_{i j t} O l d_{j, t}+\beta_{2} \sum_{j \neq i} \omega_{i j t} Y_{o u n g}, t+f_{i}+v_{i, t}
$$

We adopt here the same instrument used in the literature, i;e. the shares of old and young people, which have a good explanatory power of tax rates without influencing population pyramid. Then in a second step the predicted value of $\bar{t}_{i, t}$, denoted $\hat{t}_{i, t}$ is used in Equation (6).

\footnotetext{
${ }^{14}$ Here three years, but we have verified that the results are still verified with shorter lag (one year).

${ }^{15} \mathrm{We}$ have also used a time trend and we obtain similar result.

${ }^{16}$ More precisely these variable are the share of population older than 65 years old and younger than 14 years old. These data comes from the World Development Indicators.

${ }^{17}$ We have also used a distance weighted by population with the same results.
} 
This system is identified if and only if:

$$
\begin{gathered}
\beta_{1} \neq 0, \beta_{2} \neq 0 \\
\operatorname{Cov}\left(\sum_{j \neq i} \omega_{i j t} O l d_{j, t}, v_{i, t}\right)=0, \operatorname{Cov}\left(\sum_{j \neq i} \omega_{i j t} \operatorname{Young}_{j, t}, v_{i, t}\right)=0 \\
\operatorname{Cov}\left(\hat{t}_{i, t}, \varepsilon_{i t}\right)=0 .
\end{gathered}
$$

The first condition is about relevance requiring that conditional on controls, i.e. individual fixed effects $f_{i}$, the instrument predicts the endogenous dependent variable. The other two require that the instrument affects the dependent variables only through their impact on the average tax rate of other countries, i.e. the so-called exogeneity conditions or exclusion restrictions.

Table (??) provides the result of these two steps.

Beside Hansen test indicating that the selected instruments are strong, we can verify their validy in all column of Table (??), the proportion of old and young people significantly explained CIT rates and EATR in Europe.

Concerning the second step, we confirm the results of Overesch and Rincke (2011) about the dynamics adjustment of taxes, all our dependent variables depend significantly on past levels. More importantly the instrumented distance-weighted measures of neighbors' taxes are always significant. This result contrasts with Overesch and Rincke (2011) who do not find serious evidence of tax competition on EATR (only on CIT rates). ${ }^{18}$ Another interesting result is that the elasticity of the EATR to the averaged averaged tax rates of partners is much more larger for financial and investment assets than for industrial buildings. This result illustrates the intensity of the race to the bottom concerning the most mobile base.

Lastly, even if our dummy "crisis" is simplistic and can be critized on various grounds, it is interesting to observe that this variable does not explain tax rates on capital. Tax competition on this factor is not a temporary phenomenom due to the recent crisis.

\footnotetext{
${ }^{18}$ See Hochgatterer and Leibrecht (2012) for a survey on tax competition who discuss whether tax rates decline for institutional and political reasons (yardstick competition and common intellectual trends) not analyzed here. In their meta-analysis of the field, Costa-Font, De-Albuquerque and Doucouliagos (2014) find that tax competition produces stronger interactions than yardstick competition.
} 


\section{Consequences of capital tax competition on immo- bile factors}

\section{Theory}

The consequences of tax competition on the most mobile source are well known, they lead governments to transfer the tax burden on the less mobile bases. To illustrate this simply, and to show in addition the role of trade integration which is often neglected in the traditional literature on tax competition, we use the theoretical model presented in the previous section. In both countries, taxation on capital and labor is chosen to raise a given amount of revenue, previously denoted $G$. Without loss of generality we follow Ottaviano and van Ypersele (2005, Section 5.2) by imposing $G_{i}=0$, this implies that the tax rate on capital automatically determines the tax rate on labor to balance the budget, indeed the budget constraint is now $t_{i}^{L} L_{i}+t_{i}^{K} s_{i} r_{i}=0$. By inserting the tax rate set on capital under the simultaneous Nash game in this constraint and by resolving for $t_{i}^{L}$ we obtain the tax levied on labour when this factor is the adjustment variable in the budget function:

$$
t_{i}^{L}=\frac{\mu-\mu \phi^{2}-L(1-\rho)\left(1-2 a(\phi-1)^{2}+\phi^{2}\right)}{(2 a-1) L(\rho-1)\left(1+\phi^{2}\right)}
$$

Figure (8) reports how this tax rate is affected by the economic integration of countries in this situation of tax competition on the mobile base.

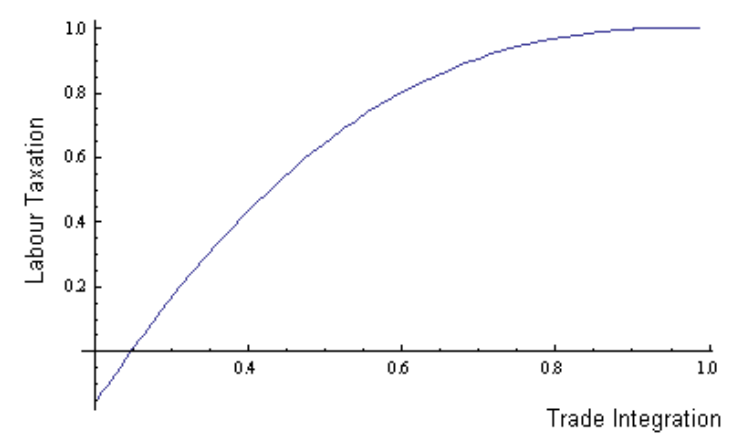

Figure 8: Labour Taxation under Tax Competition on Capital and Trade Integration. Numerical simulations done with $\rho=6, \mu=0.4, a=1, L=1$.

This gives the following result. 
Result 3 Due to tax competition, trade integration raises the burden of taxation on the immobile factor.

Trade integration leads to a race to the bottom regarding taxes on capital (see the discussion below Equation (4)) which, for a given budget, inevitably leads to raise the labour taxation.

\section{Facts}

Since the 2009 Great Recession tax competition has tended to exacerbate, with the tendency of Eurozone countries caught in severe recessions and having to consolidate their public finances to resort to 'internal devaluations', usually a mix of wage moderation, reductions in social contributions, and consumption tax hikes. For instance a 'race to the top' on VAT rates has indeed been observed since 2010 (Le Cacheux and Laurent, 2015). The level of the average VAT rate in the EU-28 seems however to have reached its apex in the recent years (Figure (9)).

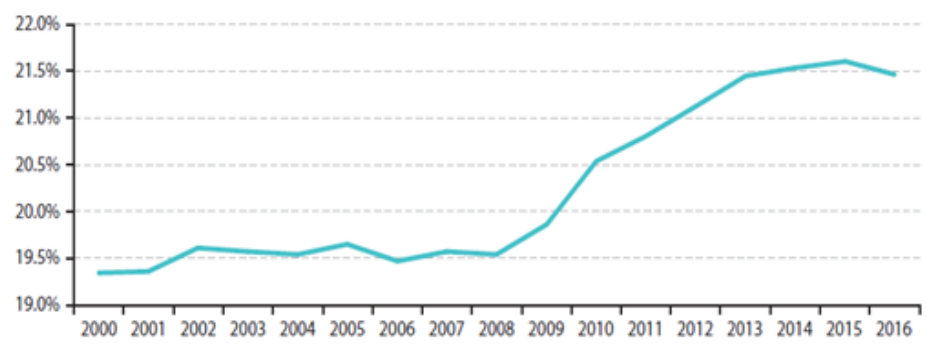

Figure 9: Average VAT rate in the EU-28.

$D G$ Taxation and Customs Union.

Labor also pays an increasing share of the tax burden. If one considers labor taxes targeted at the bottom end of the wage scale, usually reduced to boost employability of low-skilled workers, the crisis has provoked a radical change. To illustrate this Figure (10) presents the difference between labor costs to the employer and the corresponding net takehome pay of the employee, called the tax wedge on low wage workers (single worker without children at two thirds of average earnings and its developments since 2002). Whereas this tax wedge had been falling before the crisis, one can observe a rising trend up since 2008-2009. 
The implicit tax rate on labor (which is the ratio of taxes and social security contributions on employed labor income to total compensation of employees and payroll taxes) has followed the same evolution.

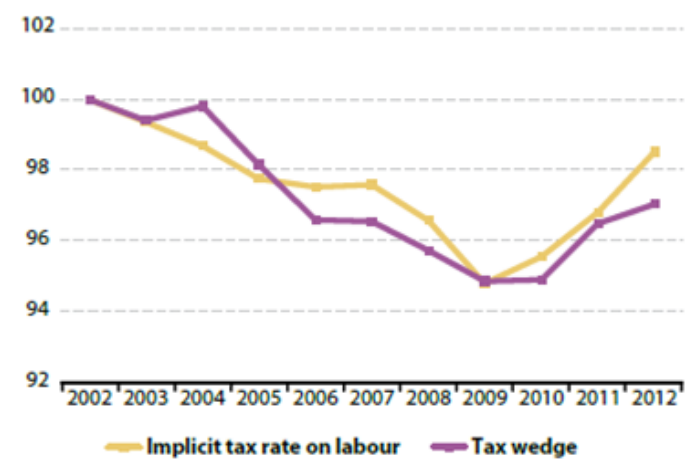

Figure 10: Indicators of tax burden on labour, EU-27, 2002-2012.

\section{Commission services and OECD.}

The dramatic decrease in tax rates on mobile firms has also led governments to revisit the definition of their tax bases. To show this the Corporate Income Tax (CIT hereafter) as a \% of GDP and as a \% of total taxation were presented in Figure (??). The relative stagnation of CIT as a \% of GDP or as a \% of total taxation contrasts with the constant decrease of the CIT rate. Actually, this apparent rate-revenue paradox may be partly explained by base broadening. ${ }^{19}$ The difficulty to tax multinational firms seems to have led governments to implement policies that broaden the corporate tax base. Devereux and Sorensen (2006) observe that on the 19 OECD countries of their sample, 11 cut their allowance rates for investment in plant and machinery between 1982 and 2004 in order to broaden their tax bases. In particular, the UK and Ireland decreased strongly their allowances from $100 \%$ to $73 \%$, and to $71 \%$ for investment in plant and machinery. The decrease in the allowance for industrial buildings has even been more dramatic, close to $90 \%$ in the 1980 s, it is now equal to zero since 2012. Kawano and Slemrod (2016) also find evidence that countries lowering their corporate tax rate, broaden their tax base. Many countries that have cut their tax rate

\footnotetext{
${ }^{19}$ Another explanation lies in the increase in the share of corporate profits in GDP coming from: a) an increase in the size of the corporate sector (e.g. less personal income tax base and more corporate legal form), b) an increase in the profitability of the corporate sector (see Sorensen, 2006; de Mooij and Nicomède, 2008).
} 
have also decreased the Present Value (PV) of their depreciation allowances.

This tendency of countries to implement policies that broaden the corporate tax base in reaction of the competition on tax rates may have some adverse consequences on competitiveness and growth. This is typically the case with the reduction of capital consumption allowances described in the previous section: when businesses are not allowed to fully deduct capital expenditures, there is a risk that they invest less. ${ }^{20}$ Exploiting a change in the UK policy concerning the first-year depreciation allowances, Maffini et al. (2016) find that when firms become qualified to this policy, there is an increase in investment rate of $11 \%$ at the mean. Similar results have been found for the US (Zwick and Mahon, 2015).

\section{Assessment: the current source-based taxation}

Previously in the text, we have presented some results regarding the lost tax revenue due to evasion, but our analysis was mainly based on anecdotal evidence, in particular on case studies reporting estimates of evasion at the firms level (Apple, Amazon etc). While we have shown that these amounts should not be minimized since they already represent a significant level of evasion (comparable to contributions of the EU of some members), they inevitably greatly under-estimate actual revenue losses. We thus follow the more general methodology recently presented by IMF (2014) to assess the efficiency of the CIT and to approximate the revenue losses. The IMF (2014) study works on OECD countries over the period 2000-2012. This analysis has been applied to the EU28 by Dover et al. (2015), who stopped their assessment in the year 2014. Our analysis differs in two ways: we do not use the same variables as the IMF and we do not work with the same sample as Dover et al. (2015). In particular we focus our attention on the EU15, which includes the main losers of tax avoidance. The focus on these countries allows not to bias the analysis by not taking into account the low tax rates of newly integrated countries that only affect marginally revenue losses. In comparison with other studies, we also focus our attention on the year 2015 which to our knowledge had not been evaluated yet. More precisely, we compute the

\footnotetext{
${ }^{20}$ In order to stimulate investment, in July 2015 the French government has enacted a temporary accelerated depreciation allowance.
} 
following indicator of tax avoidance (including, but not only, profit shifting), also called 'CIT-efficiency' $\left(E_{i t}\right)$ :

$$
E_{i t}=\frac{R_{i t}}{t_{i t} \pi_{i t}}
$$

where $R_{i t}$ is the CIT revenue, $t_{i t}$ is the tax rate, $\pi_{i t}$ is the reference tax base. When the CIT revenue is smaller than the reference, the efficiency of the CIT is below unity and thus taxation is less effective in raising revenue. Data on CIT revenue and tax rates comes from the DG Taxation and Customs Union, the approximation of the reference tax base is the "Net operating surplus: Adjusted for imputed compensation of self-employed" from AMECO, hereafter denoted NOS-adj. This contrasts with the IMF (2014) study that use Gross operating surplus (GOS). Since consumption of fixed capital might be biased by tax deduction for depreciations or by 'creative' accounting, it seems more adequate to use data on NOS that subtract these depreciation charges from the GOS in order to obtain a variable that is closer to the 'true' CIT base. Furthermore, we use the NOS-adj because the surplus above costs of self-employed individuals is taxed as personal income (and not as corporate income) and is thus not subject to CIT (see also Dover et al. 2015).

We compute this indicator for the EU-15 in 2015. The average CIT efficiency is equal to $69 \%$. This contrast with the $75 \%$ obtained by Dover et al. (2015) for the EU-28 in 2013 and with the $86 \%$ obtained by the IMF. We find that all the countries in EU-15 have a CIT-efficiency below the unity. This means that even countries like the UK, Ireland or Luxembourg fail to raise the amount of revenue that would be obtained by taxing the NOSadj at the statutory CIT rate. To better quantify this CIT-efficiency, we rewrite the previous expression as the difference between the numerator and the denominator, which represents the losses of governments due to the fact that they do not tax the NOS-adj at the CIT, the formula is the following:

$$
L_{i t}=R_{i t}-t_{i t} \pi_{i t}
$$

This difference provides a crude measure of the loss due to tax optimization. Countries that lose the most are mainly larger countries such as Germany, France, Italy, and to a lesser extent the UK. Small or middle size countries like Greece or Spain are also subject to substantial losses (see Figure 11). Computing the sum of these amounts, we find that in 2015, the revenue losses for the EU15 Member States governments due to the inefficiency 
of the CIT system amounts to $€ 198.599$ billion. ${ }^{21}$ In other words, if $100 \%$ of the tax base (NOS-adj) were taxed at the current CIT, the total gain would be equal to $€ 198.599$ billion which is higher than the current budget of the European Union. A genuine own resource can thus be financed without affecting CIT rates.

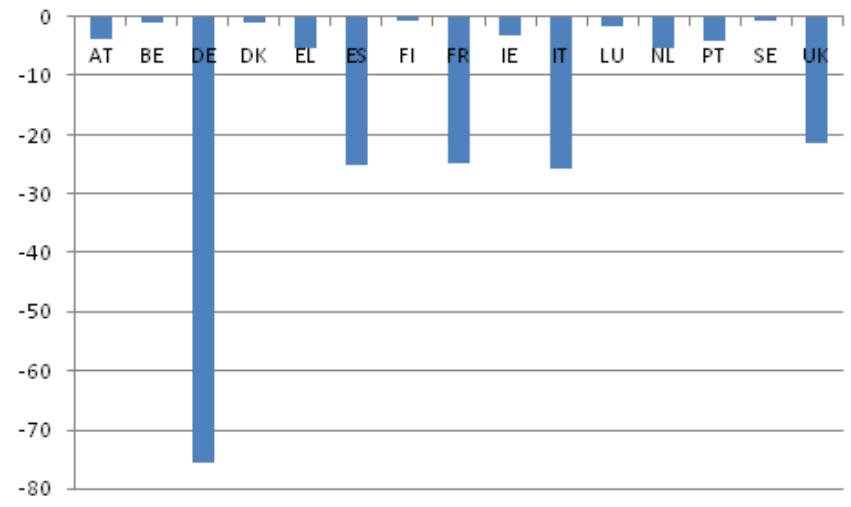

Figure 11: Revenue losses for the EU15 due to corporate tax avoidance in 2015. Authors' calculations. CIT revenue and tax rate comes from the DG Taxation and Customs Union, the approximation of the reference tax base is the "Net operating surplus: Adjusted for imputed compensation of self-employed" from AMECO.

The previous result is based on the assumption that profit shifting is the only reason of a difference between the potential and the real revenue collected by the CIT. But this difference can come from (a) differences between compliance and enforcement, and (b) differences between the tax base assumed here (NOS-adj) and the actual one. Thus whereas the previous result is extreme by considering that $100 \%$ of the difference comes from profit shifting, we make here another extreme assumption by considering that only a share $s_{i t}$ of the CIT on NOS-adj represents a revenue for each nation:

$$
L_{i t}=R_{i t}-s_{t} t_{i t} \pi_{i t}
$$

\footnotetext{
${ }^{21}$ This figure is (not much) higher than the $€ 150$ billion obtained by Murphy (2012) or the $€ 160-190$ billion of Dover et al. (2015). Differences in these estimations come from the different methodologies used but may also reflect an increase in the CIT-inefficiency in the recent period.
} 


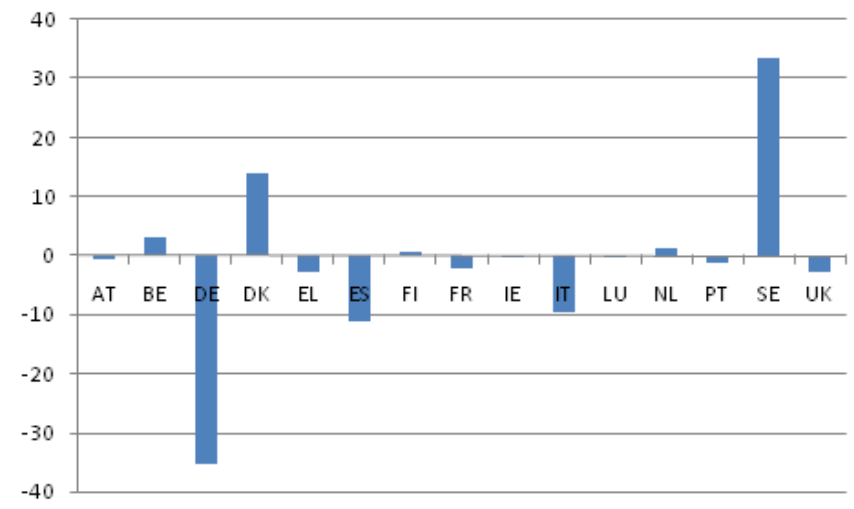

Figure 12: Revenue losses for the EU15 due to corporate tax avoidance in 2015. Authors' calculations. CIT revenue and tax rate comes from the DG Taxation and Customs Union, the approximation of the reference tax base is the "Net operating surplus: Adjusted for imputed compensation of self-employed" from AMECO.

Concerning $s_{t}$ we follow the IMF (2014) as follow:

$$
s_{t}=\sum_{E U 15} \frac{\pi_{i t}}{\sum_{E U 15} \pi_{i t}} E_{i t}
$$

where the efficiency of the CIT defined previously is weighted by the average tax base of NOS-adj. Concerning the weighted average of CIT-efficiency we find $s_{t}=0.72$ which is not too far from the simple average of CIT-efficiency obtained previously (0.69) and to the weight adopted elsewhere (e.g. 0.75 in Dover et al., 2015). The aim of this weighting scheme is to eliminate the base effects from sources not coming from profit shifting, by considering that only $72 \%$ of the NOS-adj base is taxed at the CIT rate, this computation gives our lower estimates of profit shifting: $€ 14.3652$ billion. Figure 12 reports losses and gains by countries. One can first observe some differences such as the fact that there are now winners of the tax shifting game, such as Belgium and the Netherlands. The large gains of Sweden or Denmark, not known to be a tax haven, probably simply reveals the good efficiency of their tax system and the fact that these countries have a system that rely heavily on personal income tax. One can also observe that the losses of Luxembourg and of the U.K. have shrunk in comparison with the previous results. Lastly, tax shifting is still strongly detrimental to Germany, Spain, Italy and Greece (the amount of losses is small in absolute terms, see Figure 12 , but not in relative terms, i.e. considering the size of the country) and still problematic 
for France (€2.2 billion).

These results illustrate the sensitivity of the measure of losses to the parameter defining the potential/theoretical tax base. Choosing $s_{t}=0.72$ or $s_{t}=1$ as previously gives extreme values of losses, approximately equal to $€ 15$ billion in the first case and $€ 198$ billion in the second one. Now if we take an intermediate value, $s_{t}=0.85$, which is the one used by the IMF in its study over the period 2000-2012 (to be precise $s_{t}=0.86$ ) we find that losses are still quite high, i.e. equal to $€ 97.4576$ billion in the EU15 for the year 2015. The distribution of losses and gains are similar to the one obtained in the previous scenario.

\section{European taxation on a Common Consolidated Cor- porate Tax Base}

\subsection{The EU commission proposal}

In order to reduce compliance costs and to end profit-shifting within the European single market, the EU Commission has proposed to modify in depth the current system by promoting a Common Consolidated Corporate Tax Base (CCCTB). This proposal contains a revenue-sharing mechanism i.e. a formula apportionment defining how the consolidated tax base is shared among countries. This is a radical change leading to replace the current separate accounting systems by a system whereby multinational firms should consolidate the incomes of their affiliates into a single measure of taxable income in the country of residence of their headquarters, and the taxable base then be distributed among the governments of the various countries in which they operate based on a firm's geographic distribution of different factors (e.g. payroll, property, and sales).

To illustrate this system one can take a very simple example. Consider a multinational firm located in Germany with a single subsidiary in France with the following characteristics: $60 \%$ of the capital, $30 \%$ of the payroll and $9 \%$ of the sales are located in Germany. With a formula apportionment and an equal weight (i.e. 1/3) on these factors, the multinational firm presents a consolidate income of $43 \%$ in Germany $(60 / 3+30 / 3+9 / 3=43)$ and the remainder in France. 
The formula apportionment proposed by the EC relies on three factors i.e. sales, labor and assets. Sales to take into account where income is generated (demand side), and labor and capital to represent how income is generated (supply side). The Commission also proposes to decompose the labor factor into two equally weighted factors, payroll and the number of employees. Regarding assets, only fixed tangible assets are considered, which is a limitation since intangible asset are highly mobile. The EC has however proposed to include R\&D and marketing in the future. This proposal has been approved with amendments by the European Parliament in April 2012 (68\% votes in favor) with opponents coming from Bulgaria, the Czech Republic, Hungary, Ireland, Malta, Poland and Great Britain, leading some experts to consider that a common consolidated tax base in the EU is only possible through the use of an Enhanced Cooperation Agreement. However as shown by Gérard and Princen (2012) the introduction of such a tax base by a limited number of Member States will lead to inefficient taxation and will leave room for income-shifting strategies.

In 2016, the Commission has proposed to re-launch the CCCTB with a new proposition that foresees an intermediate step in which the tax base would not be consolidated (CCTB) and only firms with annual turnover exceeding $€ 750$ million would be subject to the CCTB.

Before analyzing the effects of this proposal, it is interesting to present the US situation

and its apportionment formula that has inspired and can still inspire the implementation of a CCCTB in Europe.

\subsection{The Massachusetts formula and the question of uniformity}

Like the European Member States, the US states have lost part of their fiscal sovereignty due to the mobility of their tax base. In the early 20th century, many states started to set corporate income taxes and a federal corporate income tax was first instituted in 1909; however at the same time, firms began to grow beyond their regional boundary. For instance the Ford Motor Company founded in 1903, started to locate its factories all around the US in different large cities in the 1910s and in Europe in the 1920s. By the end of the 1930s many states adopted an apportionment formula which has progressively converged towards the "Massachusetts formula".

Like the EC proposal, this formula gives an equal weight to three factors, property, 
payroll and sales. However contrary to the European proposal, there is no uniformity in the implementation, and the weighting scheme has evolved over time. For instance, Clausing (2016) shows that the percentage of states using this formula has decreased from $80 \%$ in 1986 to $17 \%$ in 2012. An increasing number of states have adopted a single-sales formula where the entire weight is on sales (see Figure 14).

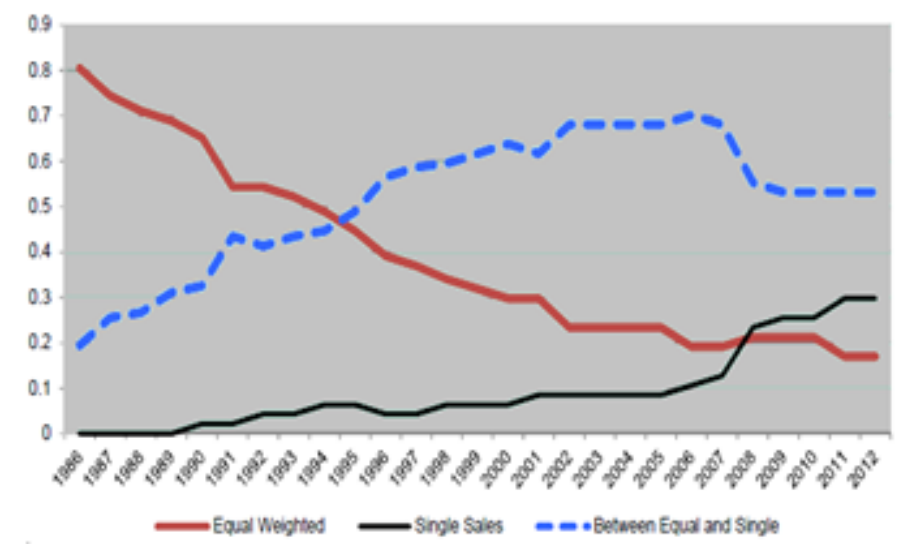

Figure 14: The decreasing importance of equal weights in the American formula. Clausing (2016).

The fact that the formula apportionment rule is not harmonized between states represents a particular problem already emphasized by McClure (1980). This author demonstrates that the apportionment formula modifies the nature of the corporate income tax that becomes a direct tax on the factors in the formula. As a result, governments strategically chose the weights of the formula to attract activities.

These externalities have been detected empirically by Goosbee and Maydew (2000), showing that the U.S. system turns partially the corporate income taxes among states into a payroll tax leading firms to optimize their tax payment by shifting the location of their production. Using a panel dataset over more than twenty years (1978-94), they find that employment increases in states where the payroll weight is reduced and decreases in other states. Reducing the payroll weight from one-third to one-quarter increases manufacturing employment around 1.1\%. Adding two decades to this database, Clausing (2016) minimizes these results for the recent period, but however underlines the possibility of harmful competition among American states. 


\subsection{Assessment on the CCCTB}

The key word of the CCCTB proposal is uniformity, uniformity of the tax base, uniformity in the rules of consolidation and the adoption of a uniform formula apportionment, but the consensus on this topic is hard to reach.

The advantage to increase the attractiveness of the European Single market by removing compliance costs and obstacles to cross-border activity may be too small and the divergent points of view of Member States on the different technical questions raised by the CCCTB are numerous. A more realistic solution may be to relax the requirement of uniformity on base, consolidation and apportionment. Such a system would obviously be less optimal and ambitious, but can nonetheless represent an improvement.

The Commission has proposed to re-launch in 2016 the CCCTB with a new proposition postponing consolidation until after the common base has been implemented, i.e. the first step of this reform would be to find an agreement on a Common Corporate Tax Base (CCTB). A number of studies offers evaluations of the potential impact on total revenue and crosscountry distribution of introducing the $\mathrm{C}(\mathrm{C}) \mathrm{CTB}$ while keeping the national statutory rates at their pre-reform level (Spengel, 2008; Spengel et al., 2012). In most cases, the reform is shown to have a minor impact on corporate effective tax rates and on overall CIT revenue (Spengel et al., 2012).

These results are obviously highly dependent on the selected apportionment formula, the total revenue from a CCTB should be higher than the sum of current national revenues from CIT since a number of multinational corporations has been benefiting from specific and sometimes extremely favorable tax treatments in some countries. Such a reform may be regarded as necessary in terms of efficiency (to reduce compliance costs, double taxation and double non-taxation) and in terms of fairness and growth.

The move to the CCTB may reduce opportunities for 'aggressive' tax optimization and likely increase the total yield of CIT in the EU. But it would still offer MNFs possibilities for shifting taxable profit to low tax rate jurisdictions. Only base consolidation would close loopholes and severely limit tax planning; but it has to be accompanied by formula apportionment. ${ }^{22}$ Obviously, as illustrated by the U.S. experience, such a system should not be

\footnotetext{
${ }^{22}$ Gérard and Traversa (2010) propose to use anti-abuse measures, known as Controlled Foreign Companies
} 
idealized. The current proposal takes the risk to bring complexity without resolving the tragedy of the harmful competition between members.

\section{Concluding remark}

It is proverbial that 'Two things are unavoidable: taxes and death', but taxes are increasingly avoidable for multinational firms in Europe. In this article we have presented the reasons of this avoidance. Trade integration, financial liberalization and technological revolutions have both facilitate tax evasion and tax competition. Many economists have proposed to reform the current system by an allocation of the tax base based on the location of sales to third parties. Such a mechanism would lead to tax profits on the least mobile elements i.e. shareholders, the companies composing the group and consumers. Auerbach and Devereux (2012) argued that this destination-based tax could operate like a Value Added Tax (VAT) but levied profits (with a deduction for labor costs). Under this system, a firm would be taxed in its place of residence by the EU if this firm sells products or earns revenue in the European Single market. The incidence of this tax would certainly fall partially on consumers (this is already the case with the current system) but the advantage is that tax avoidance would be much harder. As we have argued in this article, instead of this destination-based solution, a CIT at the European level on a specific, common consolidated base can also be a solution to tame tax competition on corporate profits, by limiting the possibilities for aggressive tax planning by multinational corporations. As argued in a number of recent reports to the European Commission and Parliament (in particular the Monti Report, 2017, and the companion study by Nuñez-Ferrer et al., 2016), once the CCCTB has been adopted, it would be technically easy to create a European corporate income tax that would be used to finance the EU budget as a genuine own resource. By taxing corporate profits at the EU level, in addition national to national taxation, such a a two-tier system, comparable to the one existing in the United States, would also introduce a vertical dimension to tax externalities, which would, in principle, dampen the incentives for horizontal tax competition. CCTB may (CFC) rules, in order to make lucrative detours no longer beneficial. These measures are however hardly compatible with EU law, in particular regarding the right of free establishment. 
be a significant step in the proposed direction, though other routes are possible. And the full benefits from a European corporate tax rate cannot be reaped unless consolidation of the tax base is achieved.

\section{References}

[1] Alstadsæter A., S. Barrios, G. Nicodème, A M Skonieczna, Antonio Vezzani, 2015. "Patent Boxes Design, Patents Location and Local R\&D," Taxation Papers 57, Directorate General Taxation and Customs Union, European Commission.

[2] Andersson, F. and R. Forslid (2003). Tax competition and economic geography. Journal of Public Economic Theory 5, 279-303.

[3] Arulampalam W, Devereux M and Maffini G. (2012), The Direct Incidence of Corporate Income Tax on Wages. European Economic Review. 56 (6), pp 1038-1054.

[4] Auerbach, M., (2016), Toxic Tax Deals, report Greens/EFA.

[5] Auerbach, A. and Devereux, M. P. (2012), Consumption and Cash-Flow Taxes in an International Setting, Oxford University Centre for Business Taxation Working Paper $12 / 14$.

[6] Baldwin, R (2016). The Great Convergence, Information Technology and the New Globalization. Harvard U Press.

[7] Baldwin R, R Forslid, Ph Martin, GIP Ottaviano and F Robert-Nicoud (2004). Economic Geography and Public Policy. Princeton U Press.

[8] Baldwin, R. E. and P. Krugman (2004), Agglomeration, Integration and Tax Harmonisation, European Economic Review, 48, 1, 1-23.

[9] Barberis, N., Thaler, R., (2004), A Survey of Behavioral Finance. in Handbook of the Economics of Finance, chap. 18, 1051-1121, in Constantinides G, M. Harris and R.M. Stulz eds., Elsevier North-Holland. 
[10] Borck, R \& P, Michael, 2006. "Agglomeration and tax competition," European Economic Review, Elsevier, vol. 50(3), pages 647-668

[11] Brennan, G., Buchanan, J., 1980. The Power to Tax: Analytical Foundations of a Fiscal Constitution. Cambridge University Press, New York.

[12] Bradford, David F., (1978), Factor Prices may be Constant, but Factor Returns are not. Economics Letters, 199-203.

[13] Candau, F. (2008.a), Urban Costs, Trade Costs and Tax Competition. Revue d'Economie Politique, Vol 118, 5, 625-661.

[14] Candau, F. (2008.b), Entrepreneurs' Location Choice and Public Policies, a Survey of the New Economic Geography. Journal of Economic Surveys. Vol. 22, Issue 5, pp. 909-952.

[15] Candau, F, Guepie G. (2018), Structural Gravity Equations Applied to African Trade. Miméo

[16] Cassette, A. and Paty, S. (2008), Tax competition among Eastern and Western European countries: With whom do countries compete?, Economic Systems 32, No. 4, $307-325$

[17] Clausing K. A. (2016) The US state experience under formulary apportionment: are there lessons for international reform? National Tax Journal 69 ( 2 ): 353 .

[18] Coeurdacier N, and H. Rey (2013), Home Bias in Open Economy Financial Macroeconomics. Journal of Economic Literature, 51(1): 63-115.

[19] Costa-Font J, F De-Albuquerque, H Doucouliagos, 2014. Do jurisdictions compete on taxes? A meta-regression analysis. Public Choice, 161(3-4), pp 451-470

[20] Crabbé K. and Vandenbussche, H. (2013), Are Your Firm's Taxes Set in Warsaw? Spatial Tax Competition in Europe, FinanzArchiv: Public Finance Analysis, Volume 69, Number 3, pp. 317-337(21) 
[21] Davies, R, Martin J, M Parenti and F Toubal, (2017), Knocking on Tax Haven's Door: Multinational Firms and Transfer Pricing. Forthcoming Review of Economics and Statistics, posted online https://doi.org/10.1162/REST_a_00673

[22] Davies, R. B. and J. Voget (2011), Tax Competition in an Expanding European Union, GEE Papers, 0033.

[23] de Mooij R. A., G. Nicodème (2008), Corporate tax policy and incorporation in the EU. International Tax and Public Finance, 15(4), pp 478-498

[24] Devereux M, P B Sorensen, (2006), The Corporate Income Tax: International Trends and Options for Fundamental Reform Working Party No. 2 of the Committee on Fiscal Affairs of the OECD.

[25] Dischinger, M., \& Riedel, N. (2011), Corporate taxes and the location of intangible assets within multinational firms. Journal of Public Economics, 95(7-8), 691-707.

[26] Dover R, B Ferrett, D Gravino, E Jones and S Merler (2015), Bringing transparency, coordination and convergence to corporate tax policies in the European Union. European Parliamentary Research Service PE 558.773.

[27] Drucker, J., (2010), Google 2.4\% Rate Shows How $\$ 60$ Billion Is Lost to Tax Loopholes. Bloomberg, October 21, 2010. http://www.bloomberg.com/news/2010-10-21/google-24-rate-shows-how-60-billion-u-s-revenue-lost-to-tax-loopholes.html.

[28] Edwards, J., Keen, M., 1996. Tax competition and Leviathan. European Economic Review 40, 113-134.

[29] Egger, P H., W Eggert, and H Winner (2010), Saving taxes through foreign plant ownership, Journal of International Economics 81 (1), pp. 99-108.

[30] European Commission (2013), Room Document No. 2 prepared for the Code of Conduct Group (Business Taxation), 22 October 2013, Tax Notes International, Doc. 2013-24148. 
[31] European Commission (2015) Corporate Income Taxation in the European Union. Commission Staff Working Document.

[32] Evers L, Miller H, C Spengel (2015), Intellectual property box regimes: effective tax rates and tax policy considerations. Int Tax Public Finance, 22:502-530.

[33] Exbrayat, N, (2017), Does Trade Liberalisation Trigger Tax Competition? Theory and Evidence from OECD Countries, 40(1), pp 88-115.

[34] Flandreau, M., (2006), Home Biases, Nineteenth Century Style, Journal of the European Economic Association 4(2-3):634-643.

[35] French K, J.M Poterba, 1991. Investor Diversification and International Equity Markets American Economic Review. 81(2). P. 222-226.

[36] Gérard, M; Princen, S (2012) : Investment and financing strategy of a multinational enterprise under alternative tax designs, CESifo Working Paper: Public Finance, No. 3838

[37] Gérard, M. and Traversa, E. (2010). Supplementing Consolidation and Apportionment with anti-abuse provisions, in Lange et al. (2010, ed.) Tax Treaties: Building Bridges between Law and Economics. International Bureau of Fiscal Documentation, IBFD, Amsterdam. 183-208

[38] Goolsbee, A. and Maydew, E. (2000) Coveting thy neighbor's manufacturing: the dilemma of state income apportionment', Journal of Public Economics 75: 125-143

[39] Gordon, RH. (1986) Taxation of Investment and Savings in the World Economy. American Economic Review vol.76(5), pp.1086-1102.

[40] Griffith, R., Miller, H., \& O'Connell, M. (2014). Ownership of intellectual property and corporate taxation. Journal of Public Economics, 112(1), 12-23

[41] Hanson G H., Raymond J. Mataloni, Jr., and M J. Slaughter (2005) Vertical Production Networks in Multinational Firms. The Review of Economics and Statistics, Vol. 87, No. 4, pp. 664-678. 
[42] Harberger, A. (1962), The Incidence of the Corporation Income Tax, Journal of Political Economy, 70, 215-40.

[43] Hassett, K A, Mathur., A. (2015). A spatial model of corporate tax incidence. Applied Economics. 47 (13), pp 1350-1365.

[44] Hochgatterer C and M Leibrecht, 2012. Tax competition as a cause of falling corporate income taxes: A survey of the empirical literature, 26(4), pp 616-648.

[45] International Monetary Fund (2014), Spillovers in International Corporate Taxation, IMF Policy Paper, May 9.

[46] Kawano L, J Slemrod, (2016), How do corporate tax bases change when corporate tax rates change? With implications for the tax rate elasticity of corporate tax revenues. International Tax and Public Finance, 23(3), pp 401-433

[47] Keen, M., and C. Kotsogiannis, 2002. Does Federalism Lead to Excessively High Taxes ? American Economic Review 92, 363-370.

[48] Kleinbard, Edward D. (2011), Stateless Income. Florida Tax Review 11(9): 699-774.

[49] Kotlikoff, Laurence J., Summers, L H., (1987), Tax Incidence, in Auerbach, Alan J., Feldstein, Martin (Eds.) Handbook of Public Economics, 2., Amsterdam: Elsevier Science, North-Holland, pp.1043-1092.

[50] Lachet-Touya, F., 2016. Horizontal and Vertical Tax Interactions in a Common Agency Game. CATT Working Paper 12.

[51] Lawless M, D McCoy, E Morgenroth, C O'Toole, (2017), The Importance of Corporation Tax Policy in the Location Choices of Multinational Firms. Forthcoming Applied Economics, https://doi.org/10.1080/00036846.2017.1412078.

[52] Le Cacheux, J., and E. Laurent (2015), Report on the State of the European Union, vol.4, Is Europe Sustainable?, Palgrave MacMillan 
[53] Maffini, G, J Xing, M Devereux, (2016), The impact of investment incentives: evidence from UK corporation tax returns. Working Papers 1601, Oxford University Centre for Business Taxation.

[54] Markusen, James R. (2002), Multinational Firms and the Theory of International Trade, MIT Press.

[55] Martin P, Rogers C, 1995. Industrial location and public infrastructure. Journal of International Economics, 39 (3-4), pp 335-351.

[56] McLure, C. (1980), The state corporate income tax: Lambs in wolves' clothing. In The Economics of Taxation, edited by H. Aaron, and M. Boskin. Washington, D.C.: Brookings Institution.

[57] Monti, Mario (2017), Future Financing of the EU, Final Report and Recommendations of the High Level Group on Own Resources, January, http://ec.europa.eu/budget/mff/hlgor/library/reports-communication/hlgorreport_20170104.pdf .

[58] Murphy, R. (2012), Closing the European Tax Gap, a report for the Progressive Alliance of Socialists and Democrats in the European Parliament.

[59] Navaretti, G Barba, and A J. Venables (2006), Multinational Firms in the World Economy. Princeton, N.J: Princeton University Press.

[60] Núñez Ferrer J, Le Cacheux J, G Benedetto, M Saunier, F Candau, C Emonnot, F Lachet-Touya, J Mortensen, A Potteau, I Taranic (2016), Study on the potential and limitations of reforming the financing of the EU budget, Report for the HLGOR, June, http://ec.europa.eu/budget/mff/hlgor/library/highlights/hlgor-studies-externalstudyonfinancingofeu-budget-june-2016_en.pdf .

[61] OECD (2013a), Addressing Base Erosion and Profit Shifting, Paris.

[62] OECD (2013b), Action Plan on Base Erosion and Profit Shifting, Paris. 
[63] OECD (2015), BEPS Action 11: Improving the analysis of BEPS, Public discussion Draft, Paris.

[64] Ottaviano, G. and T. Van Ypersele (2005), Market Access and Tax Competition, Journal of International Economics, 67, 1, 25-46.

[65] Overesch, M. and J. Rincke (2011), What Drives Corporate Taxes Down? A Reassessment of Globalization, Tax Competition and Dynamic Adjustment to Shocks, Scandinavian Journal of Economics, 113, 3,579-602.

[66] Pomerleau K, (2013), Capital Cost Recovery across the OECD. Fiscal Fact 402.

[67] Portes, R. \& Rey, H. (2005), The Determinants of Cross Border Equity Flows. Journal of International Economics, Volume 65, Issue 2, pp. 269-296.

[68] Randolph, W G., (2006), International burdens of the corporate income tax. Congressional Budget Office WP09.

[69] Saint-Etienne, Ch., and J. Le Cacheux (2005), Croissance équitable et concurrence fiscale, Rapport du Conseil d'analyse économique (CAE), n56, October.

[70] Sinn H.W. (2003). Bazaar Economy, Ifo-Viewpoint, 50.

[71] Sorensen PB, (2006), Can income taxes survive? And Should They? CESifo wp 1793.

[72] Spengel C, C Elschner, D Endres, K Finke, J Heckemeyer, (2012), Effective Tax Levels. TAXUD, Project for the EU Commission

[73] Spengel C., A. Oestreicher, C. Elschner, T. Reister, C. Ernst, M. Grünewald, K. Finke, J. Prassel, and L. Cui (2008), Study on the impact of reforms of corporate income taxation systems at the EU level on the size of the tax bases of the EU companies, using the model "European Tax Analyzer", Project for the EU Commission, TAXUD/2007/DE/325, FINAL REPORT, Centre for European Economic Research $(\mathrm{ZEW})$. 
[74] Spengel C., M. Ortmann-Babel, B. Zinn and S. Matenaer (2012), A Common Corporate Tax Base for Europe: An Impact Assessment of the Draft Council Directive on a CC(C)TB, World Tax Journal, Volume 4, No 3.

[75] UNCTAD (2015), Handbook of Statistics.

[76] Vicard, V. (2014), Transfer pricing of multinational companies and aggregate trade. WP Banque de France N555.

[77] Wilson, J.D. (1986), A Theory of Interregional Tax Competition, Journal of Urban Economics, 193, 296-315.

[78] Wilson JD, Wildasin D, (2004). Capital Tax Competition: bane or boon. Journal of Public Economics 88 1065- 1091.

[79] Zodrow, G. and P. Mieszkowski (1986), Pigou, Tiebout, Property Taxation and the Underprovision of Local Public Goods, Journal of Urban Economics, 19, 3, 356-70.

[80] Zwick E and J Mahon, (2017). Tax Policy and Heterogeneous Investment Behavior. American Economic Review, 107(1): 217-248 